\title{
Epidemiological and geographical characterization of leprosy in a Brazilian hyperendemic municipality
}

\section{Caracterização epidemiológica e geográfica da hanseníase em um município brasileiro hiperendêmico}

\section{Caracterización epidemiológica y geográfica de lepra en un municipio brasileño hiperendémico}

\author{
Lucia Helena Soares Camargo Marciano 1 \\ Andréa de Faria Fernandes Belone 1 \\ Patrícia Sammarco Rosa 1 \\ Neusa Maria Broch Coelho 2 \\ Cássio César Ghidella 2 \\ Susilene Maria Tonelli Nardi 3 \\ William Cabral Miranda 4 \\ Ligia Vizeu Barrozo 4 \\ Joel Carlos Lastória 5
}

\begin{abstract}
This study aimed to identify the distribution pattern of leprosy in a hyperendemic municipality in Brazil and determine its relationship with the clinicoepidemiological situation over 11 years. The geographic information system, MapInfo, spatial scan statistics and the Moran I index were used to analyze new cases. The digital cartographic base was used to map clusters of new paucibacillary and multibacillary cases and cases in minors under 15 years old. Socioeconomic indicators are shown using the choropleth mapping technique. A reduction in the detection coefficient, increases in high-risk spatial clusters, marked changes in the distribution of high-risk and low-risk clusters, and high-risk clusters of minors under 15 years old were observed from 2006 to 2010, showing recent illness, the presence of active foci, and overlapping of high-risk clusters of multibacillary infection in minors under 15 years old. Leprosy remains a public health problem in Rondonópolis, Mato Grosso State; the high-risk areas require an intensification of control measures and active search strategies to detect new cases.
\end{abstract}

Spatial Analysis; Geographic Information Systems; Epidemiologic Factors

\author{
Correspondence \\ L. H. S. C. Marciano \\ Instituto Lauro de Souza Lima. \\ Rod. Comandante João Ribeiro de Barros Km 5/6, Bauru, SP \\ 17034-971, Brasil. \\ lmarciano@ilsl.br \\ 1 Instituto Lauro de Souza Lima, Bauru, Brasil. \\ 2 Centro de Referência de Hanseníase e Tuberculose, \\ Rondonópolis, Brasil. \\ 3 Instituto Adolfo Lutz, São José do Rio Preto, Brasil. \\ 4 Departamento de Geografia, Universidade de São Paulo, São \\ Paulo, Brasil. \\ 5 Universidade Estadual Paulista Júlio de Mesquita Filho, \\ Botucatu, Brasil.
}




\section{Introduction}

Leprosy is a chronic infectious disease caused by Mycobacterium leprae, an intracellular parasite with tropism for skin macrophages and Schwann cells of the peripheral nervous system 1.

According to the World Health Organization (WHO), leprosy is a public health problem, with 17 endemic countries accounting for $95 \%(215,938)$ of new cases in $2010,55.5 \%(126,800)$ of them detected in India, which is the country with the highest number of new cases, followed by Brazil $(15.3 \%$ - 34,894), and Indonesia $(7.5 \%$ - 17,260) 2. In 2016, this ranking remained the same: India, with $63 \%(135,485)$ of new cases, followed by Brazil $(11.7 \%-25,218)$ and Indonesia $(7.8 \%-16,826) 3$.

Transmission occurs via the upper airways by daily contact with untreated patients with active lepromatous and borderline leprosy. Daily contact between healthy and infected family members increases the risk of developing the disease by 3.5 fold compared with the general population ${ }^{4}$. Extradomiciliary contacts (neighbors, school, work) with daily interactions with multibacillary patients also increase the risk of contracting the illness 5 . After infection, the incubation period is long and variable, and clinical manifestations occur on average 2 to 10 years later 6 .

The treatment adopted by the Brazilian Ministry of Health is multidrug therapy (MDT) with the regimens depending on the clinical form; patients are operationally classified as paucibacillary (PB) or multibacillary (MB). PB cases include the indeterminate and tuberculoid clinical forms, and patients with the borderline and lepromatous clinical forms are considered MB 5.

Although MDT has significantly improved leprosy control, it does not prevent the physical disabilities caused by the involvement of nerves. Some factors contribute to the development of disabilities, such as delayed diagnosis, lack of patient adherence to treatment and reactive episodes 6 . Throughout the world, the percentage of patients who began treatment with visible deficiencies was $5.8 \%, 6.6 \%$ and 5.9\% in 2010, 2015 and 2016, respectively, showing the late diagnosis of leprosy 3,7. Physical disabilities can reduce work potential, lead to restricted social life, psychological disorders, and they are also responsible for discrimination 8,9.

From 2003 to 2016, the overall new cases coefficient of detection had a significant decrease in Brazil. Despite of that, in 2016 the detection rate was higher than that recommended by the Brazilian Ministry of Health in the North (28.70/100,000 inhabitants), Central (30.02/100,000 inhabitants) and Northeast (19.30/100,000 inhabitants). With less than 10 cases per 100,000 inhabitants, which is the goal proposed by WHO, the disease is considered controlled in the South $(2.84 / 100,000$ inhabitants) and Southeast regions (4.17/100,000 inhabitants). The Central and North regions and the states of Mato Grosso, Tocantins, Maranhão presented hyperendemic levels (> 39.99/100,000 inhabitants) 10 .

Leprosy prevalence in Brazil changed from 4.71/10,000 inhabitants in 2000 to 1.56/10,000 inhabitants in 2010. In 2016, the ratio 1.10/10,000 was considered medium (1.0 to 4.9/10,000 inhabitants) 11 .

Mato Grosso State leads the ranking with the highest coefficient of prevalence and detection of new leprosy cases in recent years (2000-2016) 10,11. In this setting, Rondonópolis is one of the hyperendemic municipalities; it is a referral center for the treatment of leprosy for 19 towns in the south of Mato Grosso State. Although a slight reduction in detection rates was reported (5.59 in 2000 to 2.37 in 2010) in Rondonópolis 12, an increase in the number of MB cases in minors under 15 years old was observed, some already with physical disabilities at diagnosis. This observation suggests an intradomiciliary source of infection, considering the long incubation period of the disease, and denote the operational weaknesses of the health program 13 .

These indicators signal the need to improve control measures in the region, aiming at early diagnosis, increasing the number of contacts evaluated and decreasing the hidden prevalence. Thus, given the critical situation in Rondonópolis, the analysis of the spatial distribution of leprosy cases, considering the type of therapeutic regimen (PB and $\mathrm{MB}$ ) and patient age, will identify the regions with the highest number of cases. Spatial-temporal analysis enables a better understanding of the hyperendemic situation of the disease in addition to assisting the creation, implementation and reorientation of control measures. This type of study has become common for leprosy control in several regions of Brazil 14,15,16,17,18.

The purpose of this study was to analyze the spatial behavior of leprosy in the municipality of Rondonópolis and the relationship between the clinical and epidemiological aspects of the disease. 
These data may help identify priority areas, allowing to intensify active case finding using educational methods, community assessments and examination of contacts.

\section{Patients and methods}

This retrospective, observational and descriptive study has an ecological design. Historical series of leprosy cases of residents in Rondonópolis from 2000 to 2010 were pinpointed on maps to show the space-time evolution of the distribution of new cases by census tracts.

According to the 2010 demographic census (Brazilian Institute of Geography and Statistics IBGE. http://cidades.ibge.gov.br/xtras/perfil.php?codmun=510760, accessed on 15/May/2017), Rondonópolis has an area of $4,159,118 \mathrm{~km}^{2}$ and population density of 47.00 inhabitants $/ \mathrm{km}^{2}$. This population has grown steeply from 150,277 in 2000 to 195,476 in 2010, due to the location of the municipality in the state and the great work opportunities. From 2000 to 2005 , the municipality had 146 census tracts encompassing eight neighborhoods, which, from 2006 to 2010, expanded to 459 census tracts, involving 253 neighborhoods in five administrative regions: north, south, east, west and central-west.

Data for the years 2000 to 2010 were extracted from the medical records of the Leprosy and Tuberculosis Referral Center of Rondonópolis. The transcribed data included the identification number of the cases and full address, date of diagnosis, treatment regimen, completion date, and clinical form according to the Ridley \& Jopling (R\&J) classification 19, with inclusion of the indeterminate clinical form; therapeutic regimen, complications, and disability grading (WHO).

The WHO Indicator of Disabilities (GI) was used to evaluate physical disabilities. This indicator assesses physical deficiencies in leprosy, contributes to the proper surveillance of patients by health professionals and monitors the evolution of the disease 20.

\section{Inclusion criteria}

The study included all patients with leprosy living in the municipality of Rondonópolis treated between 2000 and 2010, irrespective of gender and without pre-establishing age limits.

\section{Database}

A database based on PostgreSQL, version 8 (Relational Database System Manager Open Source; https://www.postgresql.org/) was used, along with a system for data entry, both of which were accessed over the internet. The information from the forms was entered twice by two people to reduce possible transcription errors.

\section{Geographic information system}

A geographic information system, ArcGIS 9.3 (http://www.esri.com/software/arcgis/index.html), MapInfo version 7.8 (https://www.pitneybowes.com/us/location-intelligence/geographic-information-systems/mapinfo-pro.html) and a digital cartographic base of the municipality were used to determine the spatial location of new cases of leprosy, draw thematic maps, and geocode cases.

The addresses of reported cases were located using the digital cartographic base provided by the Municipal Planning Department of Rondonópolis.

Spatial analysis was performed from the geocoding of residential addresses linked to the census tract. The corresponding neighborhoods were identified to facilitate the operationalization of the results. The demographic data sources were the 2000 and 2010 censuses of the IBGE (http:// www.cidades.ibge.gov.br/xtras/temas.php?lang $=\& \operatorname{cod}$ mun $=510760 \&$ idtema $=125 \& \mathrm{search}=\mathrm{ma}$ to-grosso\%7Crondonopolis\%7Cproduto-interno-bruto-dos-municipios-2011, accessed on 10/ Mar/2015). 
Cluster analysis used the spatial scan statistics developed by Martin Kulldorff 21. Analyses were performed using the statistics freeware, SaTScan (http: \\www.satscan.org), which was developed to evaluate the geographic concentration of epidemic diseases. SaTScan works with single observations or data aggregated at the census tract level; it is widely used to detect spatial or space-time clusters, where the incidence of events may be too high or too low.

To apply spatial scan statistics, information about the area is associated with a single point within a polygon called a centroid, which is its geometric center 22 . To identify the spatial groupings in each centroid, a circle of variable radius is positioned and the number of occurrences within the circle is calculated according to indirect standardization by sex and age group, taking the whole municipality as the base. If the observed value is greater than expected, the region delimited by the circle is called a conglomerate. Otherwise, the radius of the circle is increased until it involves a new centroid. This procedure is performed until all centroids have been tested. Conventionally, the hypotheses are: H0 (no conglomerates) and $\mathrm{H} 1$ (there is conglomerate).

The hypotheses are tested using a likelihood ratio test. The cluster with the highest likelihood is considered the most probable, that is, the cluster that is least likely to have occurred by chance 23 . Primary clusters with p-value $<0.05$ and secondary clusters with p-value $<0.02$ are considered significant.

Spatial cluster testing was used as the basis to calculate $10 \%$ of the population at risk. Values with a relative risk less than one were considered low-risk clusters and those equal to or greater than one were considered high-risk.

Cartographic bases and population data from the 2000 and 2010 IBGE censuses were used; thus, data analysis was divided into two periods, 2000-2005 and 2006-2010.

Spatial groupings were generated from spatial scanning maps in the geographic information system of the total population divided into cases of minors under 15 years old (independent of clinical form), and $\mathrm{MB}$ and $\mathrm{PB}$ cases (with inclusion of population under 15 years old).

\section{Preparation of maps}

The digital cartographic base of Rondonópolis and ArcGIS 9.3 software were used to prepare maps with spatial clusters of new PB and MB leprosy cases in children under 15 years old.

The cases were aggregated by the 2000 and 2010 census tracts according to both periods. Upon detection of spatial clusters employing the SatScan software, the results were mapped using chorochromatic and choropleth techniques.

Socioeconomic indicators including average monthly nominal income of the heads of households and average number of residents per household were mapped according to choropleth cartographic techniques.

\section{Moran I index}

The Moran I index is a global autocorrelation measure that indicates the degree of spatial association in a data set, with values ranging from -1 to +1 , and value 0 indicating no correlation. This index is a weighted correlation coefficient used to determine whether adjoining areas are more similar than would be expected by random distribution 24 . The formula used to calculate the index is:

$$
I=\frac{N \sum_{i} \sum_{j} w_{i j}\left(x_{i}-\bar{x}\right)\left(x_{j}-\bar{x}\right)}{J \sum_{i} \sum_{j} w_{i j} \sum_{i}\left(x_{i}-\bar{x}\right)^{2}}
$$

where $N$ is the number of points in the study, $J$ the number of pairs of points examined, $x_{i}$ the value (e.g., disease incidence) of point $i, x_{j}$ is the value of the point $j\left(x_{i}\right.$ and $x_{j}$ are two points of close neighbors) and $w_{i j}$ is the weighting matrix. 


\section{Results}

\section{Epidemiologic profile}

From 2000 to 2010, 2,087 leprosy cases were diagnosed in Rondonópolis, $95.1 \%(1,985)$ lived in the urban area and 4.9\% (102) in rural areas. Of this total, 12\% (255) of cases were excluded from the sample because their addresses were incomplete or non-existent, giving a total of 1,832 (87.8\%) cases geocoded by address. Table 1 shows the distribution of cases between 2000 and 2010 by age, gender, operational classification, R\&J classification, disability grading at diagnosis and after completing therapy. The average age of the patients was 39.45 ( $\mathrm{SD}=17.52)$ years, $54.5 \%$ were men ( $\mathrm{p}$-value = 0.040 ) and 50.27\% were treated using MB regimen ( $\mathrm{p}$-value $=0.000$ ).

Due to data inconsistency, 19 cases were excluded, then 1,813 patients remained for spatial analysis.

Spatial clusters were observed in both periods; red circles indicate high relative risk (values $\geq 1$ ) and blue circles indicate low relative risk (values $<1$ ).

\section{Table 1}

Distribution of 1,832 new cases of leprosy, geocoded by address, according to age, gender, therapeutic regimen, Ridley \& Jopling's classification (R\&J), degree of disability at diagnosis and discharge from 2000 to 2005 and from 2006 to 2010.

\begin{tabular}{|c|c|c|c|c|c|c|c|c|c|c|c|c|c|c|c|c|c|c|c|c|c|}
\hline \multirow[t]{4}{*}{ Year } & \multirow[t]{4}{*}{$\begin{array}{l}\text { New } \\
\text { cases }\end{array}$} & \multicolumn{2}{|c|}{ Age } & \multicolumn{2}{|c|}{ Gender } & \multicolumn{2}{|c|}{$\begin{array}{l}\text { Therapeutic } \\
\text { regimen } \\
n=1,827\end{array}$} & \multicolumn{6}{|c|}{$\begin{array}{l}\text { R\&J classification, with inclusion of } \\
\text { the Indeterminate form } \\
\qquad n=1,829\end{array}$} & \multicolumn{4}{|c|}{$\begin{array}{c}\text { Degree of disability at } \\
\text { diagnosis } \\
n=1,832\end{array}$} & \multicolumn{4}{|c|}{$\begin{array}{c}\text { Degree of disability at } \\
\text { discharge } \\
n=1,832\end{array}$} \\
\hline & & $\geq 15$ & $<15$ & M & $\mathbf{F}$ & MB & PB & I & TT & BT & BB & BL & LL & 0 & 1 & 2 & NR & 0 & 1 & 2 & NR \\
\hline & & $\mathbf{n}$ & $n$ & $n$ & $n$ & $\mathrm{n}$ & $n$ & $\mathrm{n}$ & $\mathbf{n}$ & $n$ & $\mathbf{n}$ & $\mathbf{n}$ & $n$ & $\mathbf{n}$ & $\mathrm{n}$ & $\mathrm{n}$ & $\mathbf{n}$ & $\mathbf{n}$ & $n$ & $n$ & $\mathbf{n}$ \\
\hline & & $\%$ & $\%$ & $\%$ & $\%$ & $\%$ & $\%$ & $\%$ & $\%$ & $\%$ & $\%$ & $\%$ & $\%$ & $\%$ & $\%$ & $\%$ & $\%$ & $\%$ & $\%$ & $\%$ & $\%$ \\
\hline \multirow[t]{2}{*}{2000} & 173 & 156 & 17 & 93 & 80 & 71 & 102 & 5 & 91 & 38 & 15 & 8 & 16 & 142 & 16 & 4 & 11 & 69 & 1 & 0 & 103 \\
\hline & & 90.2 & 9.8 & 53.8 & 46.2 & 41.0 & 59.0 & 2.9 & 52.6 & 22.0 & 8.7 & 4.6 & 9.2 & 82.1 & 9.2 & 2.3 & 6.4 & 39.9 & 0.6 & 0.0 & 59.5 \\
\hline \multirow[t]{2}{*}{2001} & 133 & 126 & 7 & 73 & 60 & 46 & 87 & 13 & 71 & 23 & 14 & 6 & 6 & 117 & 4 & 4 & 8 & 39 & 3 & 1 & 90 \\
\hline & & 94.7 & 5.3 & 54.9 & 45.1 & 34.6 & 65.4 & 9.8 & 53.4 & 17.3 & 10.5 & 4.5 & 4.5 & 88.0 & 3.0 & 3.0 & 6.0 & 29.3 & 2.3 & 0.7 & 67.7 \\
\hline \multirow[t]{2}{*}{2002} & 161 & 149 & 12 & 86 & 75 & 59 & 102 & 5 & 86 & 42 & 15 & 4 & 9 & 124 & 12 & 6 & 19 & 46 & 7 & 5 & 103 \\
\hline & & 92.5 & 7.5 & 53.4 & 46.6 & 36.6 & 63.4 & 3.1 & 53.4 & 26.1 & 9.3 & 2.5 & 5.6 & 77.0 & 7.5 & 3.7 & 11.8 & 28.6 & 4.3 & 3.1 & 64.0 \\
\hline \multirow[t]{2}{*}{2003} & 127 & 117 & 10 & 77 & 50 & 56 & 71 & 7 & 60 & 28 & 21 & 4 & 7 & 100 & 13 & 1 & 13 & 27 & 1 & 2 & 97 \\
\hline & & 92.1 & 7.9 & 60.6 & 39.4 & 44.1 & 55.9 & 5.5 & 47.0 & 22.0 & 17.0 & 3.0 & 5.5 & 79.0 & 10.0 & 1.0 & 10.0 & 21.2 & 0.8 & 1.6 & 76.4 \\
\hline \multirow[t]{2}{*}{2004} & 149 & 139 & 10 & 89 & 60 & 74 & 75 & 11 & 59 & 47 & 22 & 5 & 5 & 100 & 17 & 6 & 26 & 9 & 0 & 0 & 140 \\
\hline & & 93.3 & 6.7 & 59.7 & 40.3 & 49.7 & 50.3 & 7.4 & 39.6 & 31.5 & 14.7 & 3.4 & 3.4 & 67.1 & 11.4 & 4.0 & 17.5 & 6.0 & 0.0 & 0.0 & 94.0 \\
\hline \multirow[t]{2}{*}{2005} & 166 & 154 & 12 & 100 & 66 & 81 & 85 & 10 & 71 & 44 & 26 & 3 & 8 & 114 & 13 & 3 & 36 & 58 & 6 & 6 & 96 \\
\hline & & 92.8 & 7.2 & 60.2 & 39.8 & 48.8 & 51.2 & 6.2 & 43.8 & 27.2 & 16.0 & 1.8 & 5.0 & 68.7 & 7.8 & 1.8 & 21.7 & 35.0 & 3.6 & 3.6 & 57.8 \\
\hline \multirow[t]{2}{*}{2006} & 153 & 144 & 9 & 76 & 77 & 80 & 73 & 11 & 61 & 42 & 20 & 8 & 11 & 117 & 16 & 9 & 11 & 74 & 3 & 7 & 69 \\
\hline & & 94.0 & 6.0 & 49.7 & 50.3 & 52.3 & 47.7 & 7.2 & 39.9 & 27.5 & 13.0 & 5.2 & 7.2 & 76.5 & 10.5 & 5.9 & 7.1 & 48.3 & 2.0 & 4.6 & 45.1 \\
\hline \multirow[t]{2}{*}{2007} & 177 & 160 & 17 & 90 & 87 & 82 & 95 & 8 & 86 & 47 & 18 & 15 & 4 & 150 & 6 & 6 & 15 & 99 & 4 & 4 & 70 \\
\hline & & 90.4 & 9.6 & 51.0 & 49.0 & 46.3 & 53.7 & 4.5 & 48.5 & 26.5 & 10.0 & 8.5 & 2.0 & 84.7 & 3.4 & 3.4 & 8.5 & 55.9 & 2.3 & 2.3 & 39.5 \\
\hline \multirow[t]{2}{*}{2008} & 205 & 185 & 20 & 111 & 94 & 134 & 71 & 11 & 66 & 81 & 27 & 11 & 9 & 65 & 3 & 2 & 135 & 65 & 3 & 2 & 135 \\
\hline & & 90.0 & 10.0 & 54.0 & 46.0 & 65.0 & 35.0 & 5.4 & 32.2 & 39.5 & 13.2 & 5.3 & 4.4 & 31.7 & 1.4 & 1.0 & 65.9 & 31.7 & 1.5 & 1.0 & 65.8 \\
\hline \multirow[t]{2}{*}{2009} & 208 & 198 & 10 & 109 & 98 & 115 & 88 & 10 & 73 & 76.0 & 28.0 & 9 & 12 & 118 & 19 & 7 & 64 & 54 & 9 & 4 & 141 \\
\hline & & 95.0 & 5.0 & 53.0 & 47.0 & 57.0 & 43.0 & 5.0 & 35.0 & 36.5 & 13.5 & 4.0 & 6.0 & 57.0 & 9.0 & 3.0 & 31.0 & 26.0 & 4.0 & 2.0 & 68.0 \\
\hline \multirow[t]{2}{*}{2010} & 180 & 165 & 15 & 94 & 86 & 123 & 57 & 16 & 45 & 71.0 & 25.0 & 12 & 11 & 117 & 19 & 8 & 36 & 38 & 9 & 1 & 132 \\
\hline & & 92.0 & 8.0 & 52.0 & 48.0 & 68.0 & 32.0 & 9.0 & 25.0 & 39.0 & 14 & 7.0 & 6.0 & 65.0 & 11.0 & 4.0 & 20.0 & 21.0 & 5.0 & 1.0 & 73.0 \\
\hline \multirow[t]{2}{*}{ Total } & 1,832 & 1,693 & 139 & 998 & 833 & 921 & 906 & 107 & 769 & 539 & 231 & 85 & 98 & 1,264 & 138 & 56 & 374 & 578 & 46 & 32 & 1,176 \\
\hline & & 92.4 & 7.6 & 54.5 & 45.5 & 50.4 & 49.6 & 6.0 & 42 & 29.5 & 12.6 & 4.6 & 5.3 & 69 & 7.5 & 3.1 & 20.4 & 31.5 & 2.5 & 2 & 64 \\
\hline
\end{tabular}

BB: borderline borderline; BL: borderline lepromatous; BT: borderline tuberculoid; F: female; I: indeterminate; LL: lepromatous; M: male; MB: multibacillary; NR: unrealized; PB: paucibacillary; TT: tuberculoid. 
Although spatial scans were performed considering up to $10 \%$ of the population at-risk, large clusters occurred in rural areas, whose census tracts were larger, a fact inherent to the analysis. As they are low-risk clusters, that is, there were less cases than expected statistically and they did not present implications for targeting actions.

\section{Therapeutic regimen}

Of the 1,813 cases, 1,808 provided information as to the treatment regimen: $51 \%$ (915) were $\mathrm{MB}$ and $49 \%$ (893) were PB patients. There were $389 \mathrm{MB}$ and $520 \mathrm{~PB}$ patients between 2000 and 2005 and 526 MB and 373 PB patients from 2006 to 2010 (Table 1).

\section{Multibacillary population}

In the period 2000-2005, the annual detection rate was 43.1/100,000 inhabitants. During this period, five significant spatial clusters were identified, two high-risk (\#3 and \#4) and three low-risk (\#1, \#2 and \#5), totaling $22 \%(85 / 389)$ of the new MB population (Figure 1$)$. The most likely significant cluster (\#1) was low-risk and composed of five neighborhoods in the central region. The two high-risk clusters accounted for 19.5\% (76/389) of the new MB cases, distributed in 3.5\% (8/8) of the neighborhoods located in the northern, eastern, western and central-western regions. Table 2 shows the characteristics and results of the spatial scan statistics of these five clusters.

The annual detection rate from 2006-2010 was 36.2/100,000 inhabitants. Six significant spatial clusters were identified, three high-risk ( $\# 1, \# 3$ and $\# 6$ ) and three low-risk ( $\# 2, \# 4$ and $\# 5$ ), comprising $34 \%(178 / 526)$ of the new MB cases (Figure 1). The statistically most likely spatial cluster (\#1) was high-risk in four neighborhoods located in the western region. From 2006-2010, the three high-risk clusters accounted for 24.5\% (129/526) of the MB cases and occupied 11.5\% (29/253) of the neighborhoods located in the western, eastern, central-western and northern regions of the municipality. Table 2 shows the characteristics and results of the spatial scan statistics of these six clusters.

Upon analysis, $6.9 \%$ reduction in the annual detection rate was observed in the second period; however, an increase was observed in the number of new MB cases, clusters, and neighborhoods with new cases. Half (50\%) of the eight neighborhoods with new cases in high-risk clusters, from 20002005, had new cases from 2006-2010: Loteamento Pedra Noventa, Vila Olinda, Parque Residencial Universitário (western region) and Cidade Natal (northern region). However, in 2006-2010, in addition to these four neighborhoods, new MB cases were diagnosed in another 25 neighborhoods of the municipality, $75.86 \%$ of which were located in the eastern region, $13.8 \%$ in the western region, $6.9 \%$ in the central-western region, and $3.4 \%$ in the northern region. Nevertheless, considering the significant high- and low-risk clusters, $47.8 \%(121 / 253)$ of the total neighborhoods had MB patients in 2010.

\section{Paucibacillary population}

Between 2000-2005, the overall detection rate of PB was 57.7/100,000 inhabitants. Five significant spatial clusters were found, one high-risk ( $\# 5$ ) and four low-risk ( $\# 1, \# 2, \# 3$ and $\# 4$ ), comprising $15.4 \%$ $(80 / 520)$ of the new PB cases (Figure 1). The statistically most likely spatial cluster was low-risk and included five neighborhoods in the southern region of Rondonópolis. The spatial distribution of the high-risk cluster included 11.2\% (58/520) of PB patients distributed in 2.6\% (6/8) of the neighborhoods in the east and north regions. Table 2 shows the characteristics and results of the spatial scan statistics of these four clusters.

From 2006 to 2010, the overall detection rate was 27.7/100,000 inhabitants. Four significant spatial clusters were identified, three high-risk ( $\# 1, \# 3$ and \#4) and one low-risk (\#2), comprising $31 \%(115 / 373)$ of new PB cases (Figure 1). The statistically most likely spatial cluster was composed of four neighborhoods of the western region. The three high-risk spatial clusters accounted for $30 \%$ $(112 / 373)$ of the PB patients and were distributed in 13\% (33/253) of the neighborhoods located in the northern, southern, eastern and western regions. Table 2 shows the characteristics and results of the spatial scan statistics of these four clusters. 


\section{Figure 1}

Spatial clusters of leprosy, characteristics of high- and low-risk clusters of the multibacillary, and paucibacillary populations from 2000 to 2005 and from 2006 to 2010 in the municipality of Rondonópolis, Mato Grosso State, Brazil.

1a) Spatial cluster of multibacillary leprosy (2000-2005)

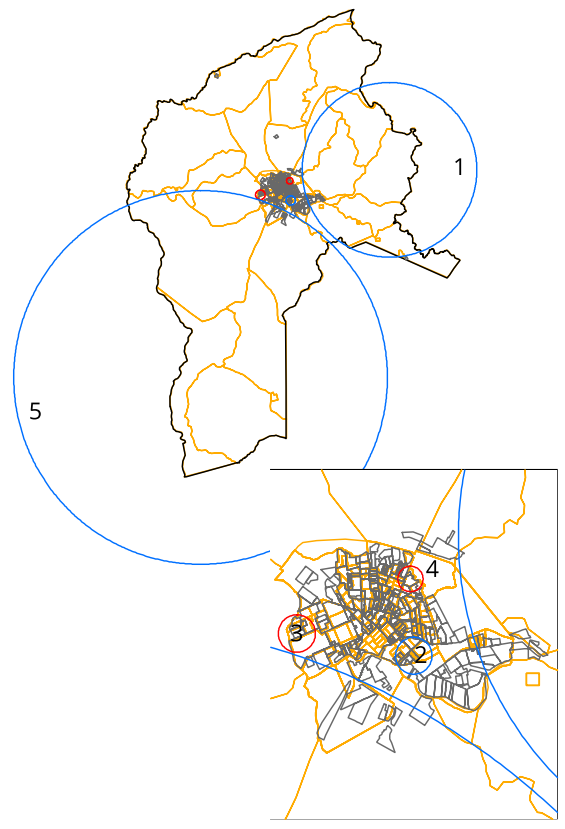

1c) Spatial cluster of paubacillary leprosy (2000-2005)

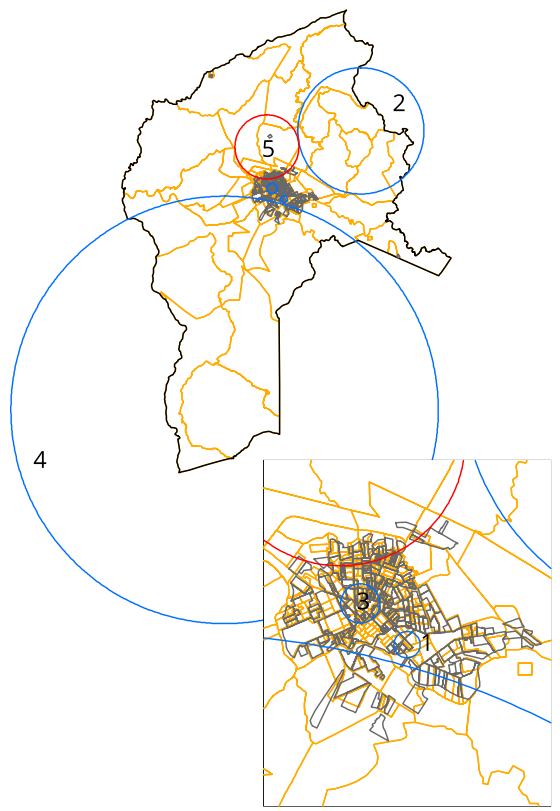

1b) Spatial cluster of multibacillary leprosy (2006-2010)
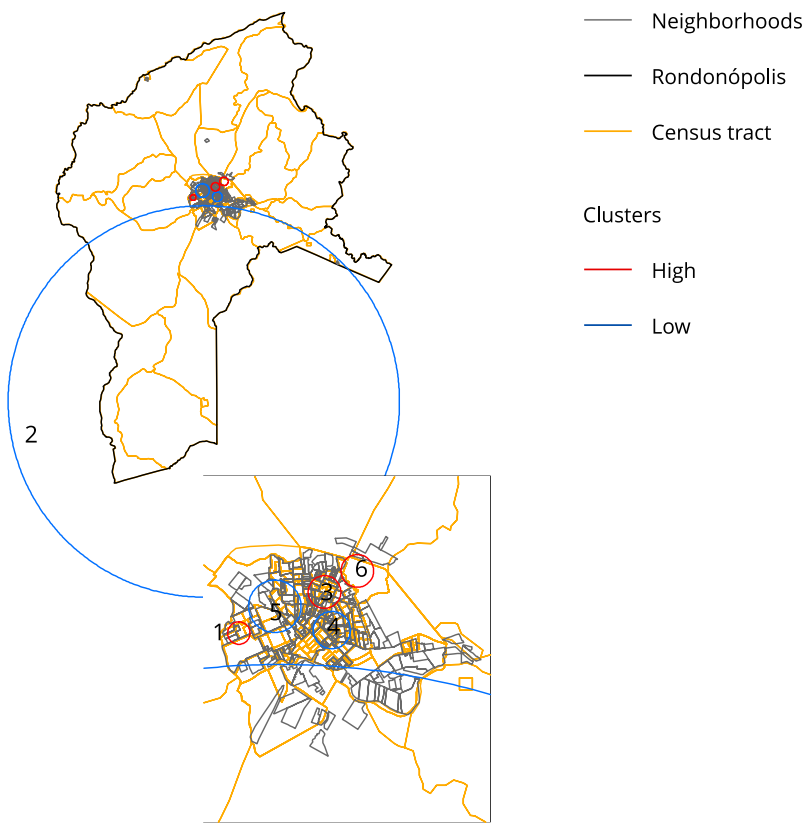

Clusters

High

1d) Spatial cluster of paubacillary leprosy (2006-2010)

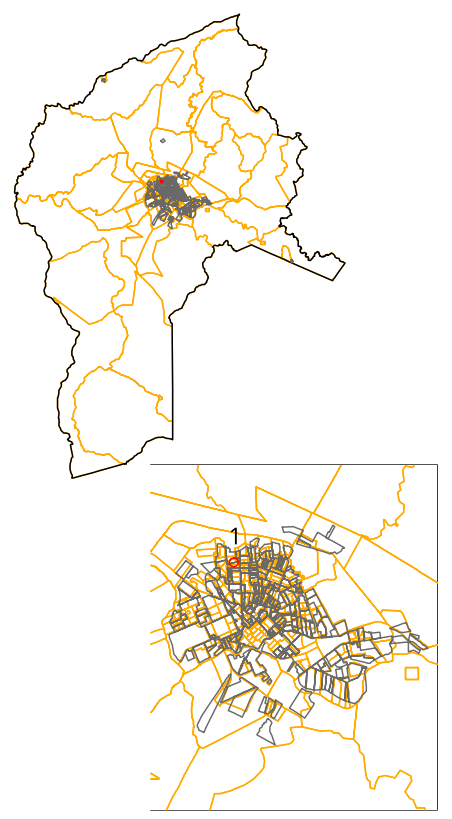

$\begin{array}{llll}0 & 510 \quad 20 \quad 30 \quad 40 & \mathrm{~km}\end{array}$ 
Table 2

Characteristics of high- and low-risk clusters and spatial scan statistics of the multibacillary (MB), paucibacillary (PB) and minors under 15 years old from 2000 to 2005 and from 2006 to 2010 in the municipality of Rondonópolis, Mato Grosso State, Brazil.

\begin{tabular}{|c|c|c|c|c|c|c|c|c|c|c|c|}
\hline Period & Population & Cluster & Inhabitants & $\begin{array}{c}\text { Cases } \\
\text { observed }\end{array}$ & $\begin{array}{c}\text { Cases } \\
\text { expected }\end{array}$ & $\begin{array}{c}\text { Cases per } \\
\text { year/10,000 } \\
\text { inhabitants }\end{array}$ & $\begin{array}{l}\text { Observed/ } \\
\text { Expected }\end{array}$ & $\mathbf{R R}$ & LR & p-value & $\begin{array}{l}\text { Cluster } \\
\text { radius }\end{array}$ \\
\hline 2000 to & MB & 1 & 8,359 & 3 & 22.12 & 5.9 & 0.14 & 0.13 & 13.619 .235 & 0.00032 & $20.670 \mathrm{~km}$ \\
\hline \multirow[t]{9}{*}{2005} & & 2 & 10,075 & 6 & 6.00 & 9.5 & 0.22 & 0.21 & 12.779 .492 & 0.00071 & $1.116 \mathrm{~km}$ \\
\hline & & 3 & 6,165 & 34 & 13.99 & 100.9 & 2.43 & 2.57 & 10.727 .660 & 0.0049 & $1.135 \mathrm{~km}$ \\
\hline & & 4 & 8,305 & 42 & 19.90 & 91.1 & 2.11 & 2.24 & 9.943 .724 & 0.010 & $769 m$ \\
\hline & & 5 & 3,592 & 0 & 9.34 & 0.0 & 0.00 & 0.0 & 9.452 .937 & 0.016 & $44.214 \mathrm{~km}$ \\
\hline & PB & 1 & 5,533 & 1 & 19.92 & 2.9 & 0.050 & 0.048 & 16.282 .872 & 0.000019 & $803 m$ \\
\hline & & 2 & 2,939 & 0 & 10.48 & 0.0 & 0.00 & 0.00 & 10.587 .174 & 0.0046 & $15.106 \mathrm{~km}$ \\
\hline & & 3 & 1,252 & 19 & 45.10 & 24.3 & 0.42 & 0.40 & 10.380 .884 & 0.010 & $1.195 \mathrm{~km}$ \\
\hline & & 4 & 4,679 & 2 & 16.06 & 7.2 & 0.12 & 0.12 & 10.085 .011 & 0.014 & $51.179 \mathrm{~km}$ \\
\hline & & 5 & 9,643 & 58 & 31.73 & 105.4 & 1.83 & 1.93 & 9.429 .962 & 0.017 & $7.667 \mathrm{~km}$ \\
\hline 2006 to & MB & 1 & 11,013 & 51 & 18.65 & 99.1 & 2.74 & 2.92 & 20.017 .073 & 0.0000026 & $685 \mathrm{~m}$ \\
\hline \multirow[t]{9}{*}{2010} & & 2 & 18,384 & 7 & 32.22 & 7.9 & 0.22 & 0.21 & 15.164 .655 & 0.00023 & $46.028 \mathrm{~km}$ \\
\hline & & 3 & 19,394 & 71 & 35.91 & 71.6 & 1.98 & 2.13 & 14.590 .267 & 0.00039 & $1.001 \mathrm{~km}$ \\
\hline & & 4 & 27,324 & 23 & 52.35 & 15.9 & 0.44 & 0.41 & 11.322 .708 & 0.010 & $1.138 \mathrm{~km}$ \\
\hline & & 5 & 24,709 & 19 & 45.26 & 15.2 & 0.42 & 0.40 & 10.471 .228 & 0.021 & $1.605 \mathrm{~km}$ \\
\hline & & 6 & 371 & 7 & 0.65 & 388.5 & 10.73 & 10.86 & 10.300 .309 & 0.022 & $999 m$ \\
\hline & PB & 1 & 7,715 & 34 & 9.68 & 90.2 & 3.51 & 3.76 & 10.224 .008 & 0.0000035 & $552 m$ \\
\hline & & 2 & 18,384 & 3 & 23.28 & 3.3 & 0.13 & 0.12 & 14.710 .157 & 0.00027 & $46.028 \mathrm{~km}$ \\
\hline & & 3 & 1,717 & 13 & 2.20 & 151.8 & 5.91 & 6.09 & 12.458 .734 & 0.0023 & $266 \mathrm{~m}$ \\
\hline & & 4 & 28,648 & 65 & 36.37 & 45.9 & 1.79 & 1.95 & 10.364 .773 & 0.017 & $4.235 \mathrm{~km}$ \\
\hline$<15$ years & & 1 & 849 & 8 & 0.83 & 187.3 & 9.60 & 10.76 & 11.328 .021 & 0.0022 & $398 m$ \\
\hline
\end{tabular}

LR: likelihood ratio; RR: relative risk.

Upon analysis of the two periods, there was $32 \%$ reduction in the overall detection rate in the latter period, with a decrease in the number of PB patients, increase in spatial clusters and regions and neighborhoods with new cases. Half (50\%) of the six neighborhoods with new cases in high-risk clusters, from 2000-2005, had new cases from 2006-2010: Vila Olga Maria (eastern region), Jardim das Flores and Jardim dos Reis (northern region). However, between 2006-2010, in addition to these three neighborhoods, new PB cases were identified in another 30 neighborhoods of the city located in the eastern (42.4\%), northern (39.4\%), western (12.12\%) and southern (6\%) regions.

Considering the significant high- and low-risk clusters, $23.3 \%(59 / 253)$ of the city's neighborhoods had MB cases in 2010.

\section{Population under 15 years old}

Between 2000-2010, 135 cases of minors under 15 years old were geocoded, 68 cases from 2000-2005 and 67 from 2006-2010.

Between 2000-2005, the annual detection rate was 25.4/100,000 inhabitants but no significant spatial clusters were identified.

However, from 2006-2010, the annual detection rate was 19.5/100,000 inhabitants and one significant high-risk spatial cluster was identified comprising $6 \%(8 / 135)$ of the new cases of minors under 15 years old (Figure 2). In the latter period, 1.2\% (3/253) of the city's neighborhoods made up the single high-risk cluster, being the statistically most likely spatial cluster located in the western region (Parque Residencial Universitário, Vila Olinda, Jardim Ana Carla). Table 2 shows the features and spatial scan statistics. 


\section{Figure 2}

Spatial clusters and characteristics of the high-risk group and spatial scan statistics of minors under 15 years old from 2006 to 2010 in the municipality of Rondonópolis, Mato Grosso State, Brazil.

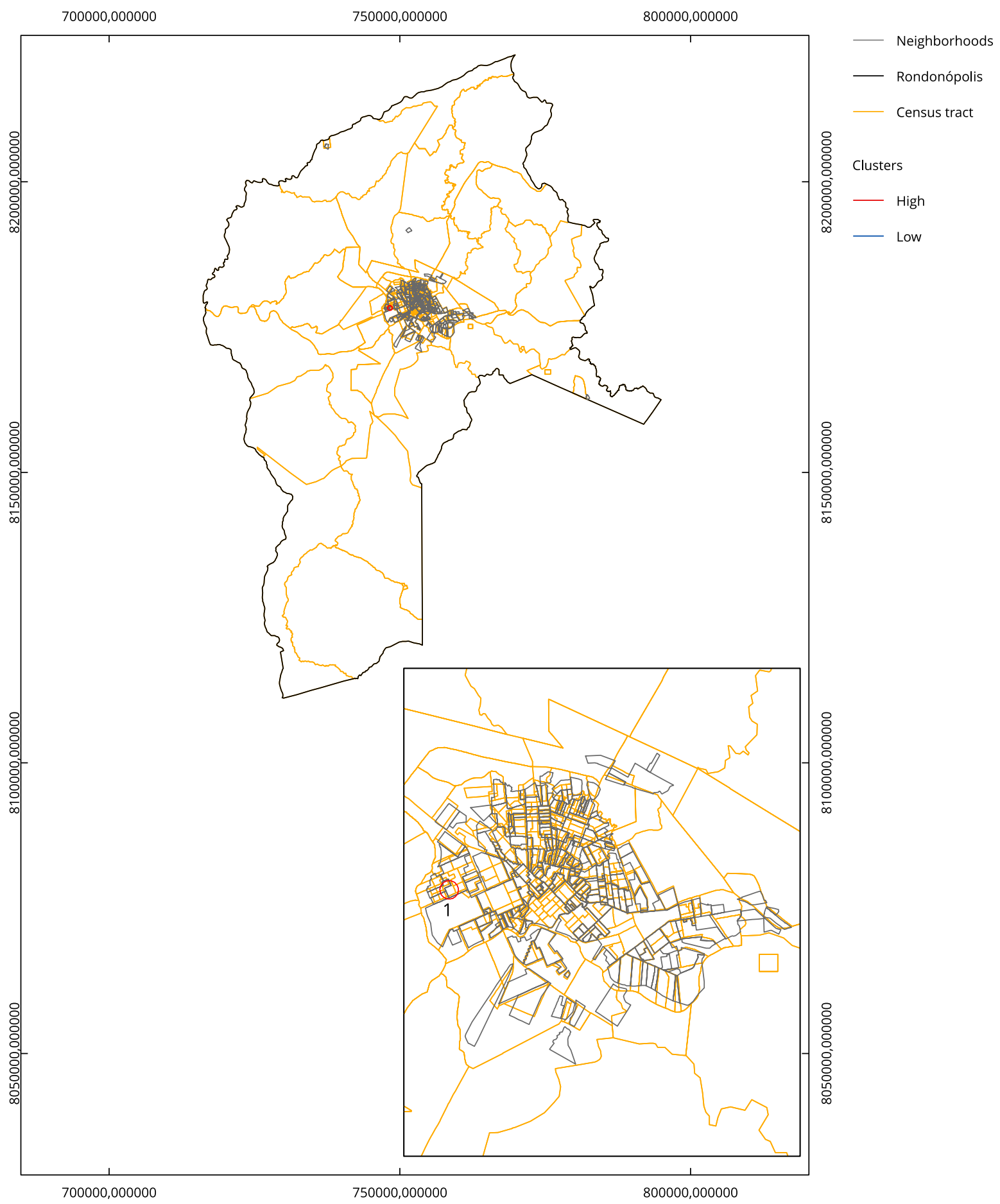

\begin{tabular}{llllll}
0 & 1 & 2 & 4 & 6 & $8 \mathrm{~km}$ \\
\hline & 1 & & & &
\end{tabular} 


\section{Moran I index}

The autocorrelation spatial test for the relative risk of leprosy in the total population of Rondonópolis showed a significant result ( $\mathrm{p}$-value $=0.001)$ in both periods. In the period 2000-2005, the index was 0.34, and in 2006-2010, the result was 0.09 (Figure 3). Although statistically significant, one should interpret the results with caution, noting that the small magnitude of the spatial autocorrelation index suggests a weak spatial clustering pattern. These results show that the spatial patterns of both periods are not random. The tendency for overall clustering was stronger between 2000 and 2005 than in the second period, justifying the search for other variables to help explain this spatial behavior.

\section{Socioeconomic indicators}

The average number of residents in households by census tract remained between 3.1 and 4.0, according to IBGE. The average monthly nominal income of the heads of households in 2000 ranged from BRL 0.0 to BRL 500.00 and in 2010 increased from BRL 500.01 to BRL 1,000.00.

\section{Discussion}

Of the 1,832 new cases diagnosed and geocoded in Rondonópolis, there was a predominance of male patients. This finding corroborates the literature, which shows that in many regions of the world, including Brazil, there is a predominance of men with leprosy 25,26,27,28. Other studies, however, revealed no significant differences in gender distribution 29,30. Furthermore, other studies report a prevalence of women with the disease 31,32 possibly related to their current exposure to different social contexts 33 .

A higher prevalence of cases of MB leprosy were diagnosed (51\%). However, when analyzing historical series, the increase in the number of MB patients (35\%) started in 2006. This may be attributed to the prevalence of tuberculoid and borderline-tuberculoid leprosy forms, which were treated with PB regimen in the first half of this study (2000-2005). Coelho 12 reported the high relapse rates among borderline-tuberculoid patients treated with PB regimen. More recently, however, the therapeutic regimen changed to $\mathrm{MB}$ in borderline-tuberculoid patients with 2+ bacilli in the lesion. This approach allowed early diagnoses of MB cases, which helped to avoid relapses and reduced transmission $12,34,35$.

According to some authors, predominance of MB patients means late diagnosis and maintenance of the leprosy transmission chain 36,37. Regarding R\&J classification, more than 50\% of cases in Rondonópolis consist of $\mathrm{PB}$, which are probably not responsible for transmission. According to the Pan American Health Organization (PAHO) 38, household contacts of PB patients have twice the risk of contracting the disease compared with subjects who do not have household contacts with leprosy. However, contacts of MB patients have a 4- to 10-fold higher risk of acquiring the disease 38. Upon analysis of the neighborhoods in high-risk clusters of PB patients, $73 \%$ also had cases of MB patients. However, MB cases were not identified in nine neighborhoods. Thus, it is possible that the stability in the detection rate is caused by the hidden prevalence, despite the prevalence coefficient having reduced from 13.82 in 2000 to 7.52 in 2010. Corroborating our results, Queiróz \& Scatena 28, in 19962007, observed a predominance of the indeterminate and tuberculoid forms in the Rondonópolis region and an increase in the borderline form during that period.

The assessment of the disability grading in the Leprosy and Tuberculosis Referral Center of Rondonópolis was classified as regular (79.6\%) at the time of diagnosis and poor (35.8\%) at discharge. The presence of Grade 2 disabilities at diagnosis indicates delayed diagnosis. However, 3\% of Grade 2 disabilities at diagnosis and $1.7 \%$ at discharge does not reflect the local reality, as a high number of patients were not evaluated at diagnosis (20.4\%), and fewer (64.2\%) were evaluated at discharge. These results demonstrate that managers and health professionals need to overcome operational difficulties to ensure the assessment of patients at diagnosis and at discharge, so they can be properly evaluated and regularly monitored to prevent disabilities. 


\section{Figure 3}

Moran I index of the relative risk of the total population in the census tracts of Rondonópolis, Mato Grosso State, Brazil.

3a) $2000-2005$

Moran's I: 0.3418

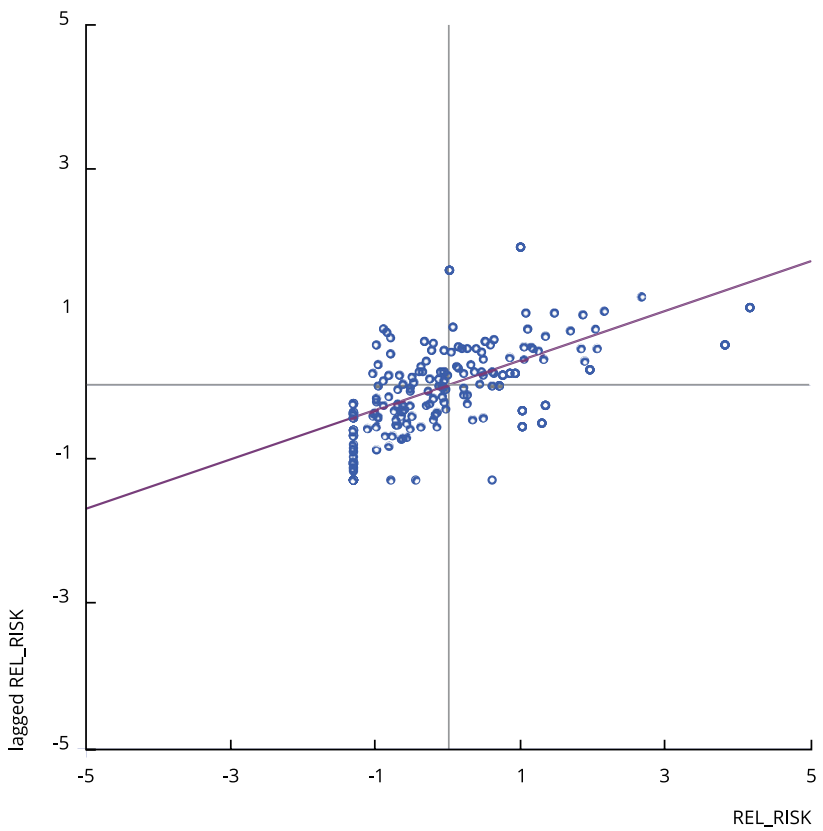

3b) $2006-2010$

Moran's |: 0.0901747

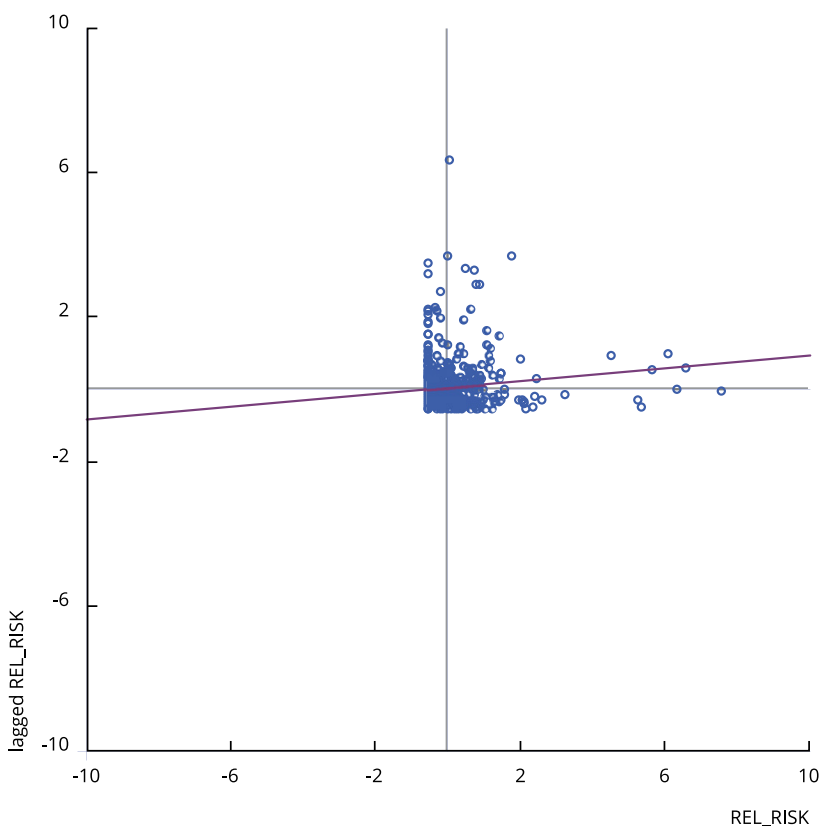


Comparing the high- and low-risk spatial clusters in both study periods, the detection rate of the disease decreased. The spatial patterns of the two periods were not random, in the first period there was a trend of stronger overall clustering compared with the second; however, the municipality remained hyperendemic, with an increase in the number of high-risk spatial clusters in the second period.

Observing the distribution of leprosy in the city from 2000-2010, 47.8\% (121/253) of the neighborhoods had new MB cases distributed between high- and low-risk clusters in the northern, eastern, western and central-western regions, demonstrating the spread of the disease across the city except in the southern region.

By analyzing these clusters, four neighborhoods were considered high-risk throughout the study period in the western (Loteamento Pedra Noventa, Vila Olinda and Parque Universitário) and northern regions (Cidade Natal). It is possible that there is still hidden prevalence in these neighborhoods, being necessary to intensify surveillance measures.

In the first studied period, there was no spatial clustering of children under 15 years old. However, in the second half of the study, while the number of cases were virtually the same, there was a highrisk cluster covering part of the western region (Parque Residencial Universitário, Vila Olinda and Jardim Ana Carla). These neighborhoods also presented clusters of high-risk MB patients with the proportion of MB leprosy among 15-year-olds, being 7.4\% and 25.4\% in the first and second periods, respectively. These data, according to Souza et al. ${ }^{39}$, indicate that children have been infected very early, as the incubation period is longer for the MB forms. Studies show that the detection of cases in children under 15 years old is related to recent disease outbreaks and active transmission within families or among contacts, reinforcing the need to prioritize surveillance measures in these regions and intensify the assessments of communicants 14,40 .

Throughout the study period, the western (Vila Olinda, Loteamento Pedra Noventa, Parque Residencial Universitários), northern (Jardim das Flores, Cidade Natal and Jardim dos Reis) and eastern (Vila Olga Maria) regions comprised high-risk spatial clusters for all stratified populations, identifying a need to intensify priority actions of health surveillance.

The cartographic bases and population data of the 2000 and 2010 IBGE censuses were used for spatial analysis. According to the data provided by the Rondonópolis Regional Health Department for 2016, no significant changes were found in epidemiological data of leprosy in the municipality compared with the study period. Most (64.2\%) of the new leprosy cases resided in the same regions identified in the study, possibly indicating the maintenance of these clusters. One of the limitations of this study is the use of very large radius to search clusters, sometimes encompassing much of the city, which makes the results less informative, especially in terms of targeting actions. However, most of the large clusters identified are low-risk clusters. Thus, the results strengthen the need for intervention mainly in the areas of high-risk spatial clustering.

By analyzing some socioeconomic indicators of the western, northern and eastern regions, we observed that the neighborhoods of these regions are located in the outskirts. This study was unable to assess the number of rooms and conditions of each household. Thus, the data did not allow us to infer whether the number of inhabitants was associated with the distribution pattern of high- and low-risk groups.

The average monthly annual income of heads of households increased in the second period. Despite this increase, the neighborhoods in the western, northern and eastern regions are located in areas where the population has poor living conditions. These results agree with other studies showing that the rates of leprosy are higher in regions with low socioeconomic levels 13,41,42.

During the study period, the population increased by $30 \%$, with $43 \%$ of the current population migrating from other states in search of work 43; $17 \%$ of the migrated population came from endemic areas for leprosy (Minas Gerais: 7\%; Goiás: 4\%; Bahia: 4\%; Maranhão: 1\%; Ceará: 1\%). In 1983, the PAHO suggested that migration and urbanization increase the risk of leprosy proliferation, hindering the control 44, as shown by recent studies 41,42 .

Rondonópolis showed high economic growth with the establishment of several large companies over the last 11 years. This growth, according to Demamann 45, occurred mainly in the outskirts resulting in urban voids, requiring investments in real estate and public transport. Despite the growth and better distribution of the average monthly income, the social structure of the city is still precarious 
due to the concentration of income. Thus, on one hand there were several neighborhoods with asphalt, sewage and lighting, on the other, pockets of poverty. Gini index measures social inequality expressed in the range from 0 to 1 , where 0 is the situation of total equality and 1 complete inequality. The index of the city of Rondonópolis decreased from 0.58 in 2000 to 0.52 in 2010; despite having declined, inequality is still high. This inequality of income and capital prevails, causing social discrepancies until today 43 (http://cidades.ibge.gov.br/xtras/perfil.php?codmun=510760, accessed on 11/Nov/2012).

Confirming these findings, an absence of high-risk clusters is observed in the southern region, which is considered a prime area in the city, despite a few cases of the disease during the study period.

By analyzing the health care in the seven neighborhoods in the western, northern and eastern regions with high-risk clustering in both periods, all neighborhoods had coverage of the family health program, but there was no significant impact on reducing the endemic. The proportion of evaluated household contacts fluctuated between $8.3 \%$ and $75.8 \%$ during the study period, the average was $41.6 \%$, considered poor rate $(<50 \%)$, thus transmission may remain active. This suggests that monitoring of contacts was neglected by the health services and professionals.

Other possible explanations for the maintenance of the high endemicity are operational difficulties in the decentralization of the program and staff turnover, allied to social problems, poor living conditions and sanitation. These result in late diagnoses of MB cases, as well as the increase in new cases diagnosed with physical disabilities and the increase in children under 15 years old signal a hidden endemic in the municipality.

In Brazil, an endemic country with heterogeneous distribution, this type of study can be extended to other regions. Annual spatial monitoring in endemic regions can significantly help to identify foci of leprosy and increase the degree and intensity of directed health measures.

Thus, this study clearly shows leprosy as a current public health problem in Rondonópolis, considering the reduction of the overall detection rate and the increase in clusters in all stratified populations, the marked changes in the distribution of high- and low-risk clusters, the detection of a high-risk cluster of children under 15 years old in 2006-2010 with recent infection, the presence of active foci, and the overlap of the high-risk cluster of the population of MB patients and children under 15 years old. High-risk areas such as the western region require further control measures and active search strategies to detect new cases and evaluate communicants. Furthermore, patients need to be evaluated and monitored to prevent disabilities, from diagnosis up to five years after discharge.

The results of this study already assisted the Municipal Health Department of Rondonópolis to plan actions to intensify control measures in the regions and neighborhoods most affected by leprosy. The strategies used were active searches for cases among schoolchildren and their contacts, educational actions and evaluations of communities, as most consultations are from spontaneous demand, resulting in late diagnosis and maintenance of the transmission chain.

\section{Contributors}

L. H. S. C. Marciano contributed to the design and delineation of the project, data collection and analysis, writing and discussion of the article. A. F. F. Belone and P. S. Rosa contributed to the design of the project, data collection, data analysis, review and discussion of the article. N. M. B. Coelho and C. C. Ghidella contributed to data collection and review of the article. S. M. T. Nardi contributed to the design of the project, data collection and review of the article. W. C. Miranda and L. V. Barrozo contributed to spatial analysis and data interpretation. J. C. Lastória contributed to data analysis, writing and discussion of the article.

\section{Acknowledgments}

The authors thank Leonil Junior for georeferencing the leprosy cases analyzed herein and Fundação Paulista Contra Hanseníase for the financial support. 


\section{References}

1. Rodrigues LC, Lockwood DNJ. Leprosy now: epidemiology, progress, challenges, and research gaps. Lancet Infect Dis 2011; 11:464-70.

2. World Health Organization. Global leprosy situation, 2012. Wkly Epidemiol Rec 2012; 87:317-28.

3. World Health Organization. Global leprosy update 2016: time for action, accountability and inclusion. Wkly Epidemiol Rec 2017; 92:50120.

4. Duppre NC. Risco de desenvolver hanseníase em contatos de pacientes, segundo positividade ao teste anti PGL-I e situação vacinal (BCG) [Doctoral Dissertation]. Rio de Janeiro: Escola Nacional de Saúde Pública Sergio Arouca, Fundação Oswaldo Cruz; 2008.

5. Ministério da Saúde. Guia de vigilância epidemiológica. 7a Ed. Brasília: Ministério da Saúde; 2009. (Caderno 7, Hanseníase Paracoccidioidomicose Tuberculose).

6. Lastória JC, Abreu MAMM. Hanseníase: diagnóstico e tratamento. Diagn Tratamento 2012; 17:173-9.

7. World Health Organization. Global leprosy update 2015: time for action, accountability and inclusion. Wkly Epidemiol Rec 2016; 91:40520.

8. Corrêa BJ, Marciano LHSC, Nardi ST, Marques T, Assis TF, Prado RBR. Associação entre sintomas depressivos, trabalho e grau de incapacidade na hanseníase. Acta Fisiatr 2014; 21:1-5.

9. Garbin CAS, Garbin AJÍ, Carloni MEOG, Rovida TAS, Martins RJ. The stigma and prejudice of leprosy: influence on the human condition. Rev Soc Bras Med Trop 2015; 48:194-201.

10. Ministério da Saúde. Taxa de detecção geral de hanseníase por 100.000 habitantes. Estados e regiões, Brasil, 1990 a 2016. http://portalarquivos.saude.gov.br/images/pdf/2017/julho/10/ Taxa-de-detec----o-geral-de-hansen--ase -1990a2016-.pdf (accessed on 10/Oct/2017).

11. Ministério da Saúde. Taxa de prevalência de hanseníase por 10.000 habitantes. Estados e regiões, Brasil, 1990 a 2016. http://portalarquivos.saude.gov.br/images/pdf/2017/julho/10/Taxa-de-preval--ncia-de-hansen--ase -1990a2016-.pdf (accessed on 10/Oct/2017).

12. Coelho NMB. Caracterização dos casos de recidiva de hanseníase diagnosticados entre 1994 e 2010 no município de Rondonópolis-MT [Masters Thesis]. Goiânia: Pontifícia Universidade Católica de Goiás; 2013.

13. Freitas RS, Duarte LC, Garcia LP. Leprosy in Brazil and its association with characteristics of municipalities: ecological study, 2009-2011. Trop Med Int Health 2014; 19:1216-25.

14. Barreto JG, Guimaraes LS, Frade MAC, Rosa PS, Salgado CG. High rates of undiagnosed leprosy and subclinical infection amongst school children in the Amazon Region. Mem Inst Oswaldo Cruz 2012; 107 Suppl 1:60-7.
15. Barreto JG, Bisanzio D, Guimarães LS, Spencer JS, Vazquez-Prokopec GM, Kitron U, et al. Spatial analysis spotlighting early childhood leprosy transmission in a hyperendemic municipality of the Brazilian Amazon region. PLoS Negl Trop Dis 2014; 8:e2665.

16. Santos, ES. Aspectos geográficos e epidemiológicos da hanseníase em Cuiabá e Várzea Grande - MT [Doctoral Dissertation]. São Paulo: Faculdade de Filosofia, Letras e Ciências Humanas, Universidade de São Paulo; 2012.

17. Ignoti E, Rodrigues AM, Andrade VLG, Valente JG. Aplicação de métodos de estimativa da prevalência de hanseníase no Estado de Mato Grosso. Rev Bras Epidemiol 2004; 7:155-66.

18. Silva CLM, Fonseca SC, Kawa H, Palmer DOQ. Spatial distribution of leprosy in Brazil: a literature review. Rev Soc Bras Med Trop 2017; 50:439-49.

19. Ridley DS, Jopling WH. Classification of leprosy according to immunity, a five-group system. Int J Lepr 1966; 34:255-73.

20. Declercq E. Reflections on the new WHO leprosy indicator: the rate of new cases with grade 2 disabilities per 100,000 population per year. Lepr Rev 2011; 82:3-5.

21. Kulldorff M. A spatial scan statistic. Commun Stat Theory Methods 1997; 26:1481-96.

22. Ministério da Saúde. Introdução à estatística espacial para a saúde pública. Brasília: Ministério da Saúde; 2007.

23. Barcellos C, Ramalho W. Situação atual do geoprocessamento e da análise de dados espaciais em saúde no Brasil. Informática Pública 2002; 4:221-30.

24. Cliff AD, Ord JK. Spatial processes: models and applications. London: Pion Press/Taylor \& Francis; 1981.

25. World Health Organization. Leprosy update, 2014. Wkly Epidemiol Rec 2015; 90:461-76.

26. Melão S, Blanco LFO, Mounzer N, Veronezi CCD, Simões PWTA. Perfil epidemiológico dos pacientes com hanseníase no extremo sul de Santa Catarina, no período de 2001 a 2007. Rev Soc Bras Med Trop 2011; 44:79-84.

27. Ribeiro Junior AF, Vieira MA, Caldeira AP. Perfil epidemiológico da hanseníase em uma cidade endêmica no Norte de Minas Gerais. Rev Bras Clín Méd 2012; 10:272-7.

28. Queiróz ML, Scatena JHG. Distribuição espacial e temporal da hanseníase em Mato Grosso, no período de 1996 a 2007. Cad Saúde Colet (Rio J.) 2009; 17:145-61.

29. Duraes SMB, Guedes LS, Cunha MD, Magnanini MMF, Oliveira MLWDR. Estudo epidemiológico de 107 focos familiares de hanseníase no município de Duque de Caxias - Rio de Janeiro, Brasil. An Bras Dermatol 2010; 85: 339-45. 
30. Lima HMN, Sauaia N, Costa VRL, Coelho Neto GT, Figueiredo PMS. Perfil epidemiológico dos pacientes com hanseníase atendidos em Centro de Saúde em São Luís, MA. Rev Bras Clín Méd 2010; 8:323-7.

31. Martins BDL, Torres FN, Oliveira MLWDR. Impacto na qualidade de vida em pacientes com hanseníase: correlação do Dermatology Life Quality Index com diversas variáveis relacionadas à doença. An Bras Dermatol 2008; 83:3943.

32. Sousa MCM, Gomes ALM, Bezerra VMS. Comportamento epidemiológico da hanseníase no município de Pombal - PB. Revista Saúde. com 2010; 6:31-41.

33. Lana FCF, Rocha SMM. Organização tecnológica do trabalho em hanseníase com a introdução da poliquimioterapia. In: Almeida MCP, Rocha SMM, organizadores. O trabalho de enfermagem. São Paulo: Cortez Editora; 2000. p. 113-50.

34. Sanches LAT, Pittner E, Sanches HF, Monteiro MC. Detecção de casos novos de hanseníase no município de Prudentópolis, PR: uma análise de 1998 a 2005. Rev Soc Bras Med Trop 2007; 40:541-5.

35. Vásquez FG, Parente RCP, Pedrosa VL. Hanseníase em Coari: aspectos epidemiológicos da doença na região do médio Solimões no estado do Amazonas. Cad Saúde Colet (Rio J.) 2008; 16:193-204.

36. Lastória JC, Putinatti MSMA. Utilização de busca ativa de hanseníase: relato de uma experiência de abordagem na detecção de casos novos. Hansen Int 2004; 29:6-11.

37. Lana FCF, Amaral EP, Franco MS, Lanza FM. Estimativa da prevalência oculta da hanseníase no Vale do Jequitinhonha - Minas Gerais. REME Rev Min Enferm 2004; 8:295-300.
38. Organização Pan-Americana da Saúde. Manual para o controle da lepra. 2a Ed. Washington DC: Organização Pan-Americana da Saúde; 1989.

39. Souza WV, Barcellos CC, Brito AM, Carvalho MS, Cruz OG, Albuquerque MFM, et al. Aplicação de modelo bayesiano empírico na análise espacial da ocorrência de hanseníase. Rev Saúde Pública 2001; 35:474-80.

40. Lapa TM, Albuquerque MFPM, Carvalho MS, Silveira Júnior JC. Análise da demanda de casos de hanseníase aos serviços de saúde através do uso de técnicas de análise espacial. Cad Saúde Pública 2006; 22:2575-83.

41. Cabral-Miranda W, Chiaravalloti Neto F, Barrozo LV. Socio-economic and environmental effects influencing the development of leprosy in Bahia, north-eastern Brazil. Trop Med Int Health 2014; 19:1504-14.

42. Magalhães MCC, Santos ES, Queiroz ML, Lima ML, Borges RCM, Souza MS, et al. Migração e hanseníase em Mato Grosso. Rev Bras Epidemiol 2011; 14:386-97.

43. Associação Comercial Industrial e Empresarial de Rondonópolis; Prefeitura Municipal de Rondonópolis. Perfil Rondonópolis 2012: geografia, demografia, economia. Rondonópolis: Associação Comercial Industrial e Empresarial de Rondonópolis; 2012.

44. Organização Pan-Americana da Saúde. Manual para o controle da hanseníase. Washington DC: Organização Pan-Americana da Saúde; 1983.

45. Demamann MTM. Rondonópolis - MT: campo, cidade e centralidades [Doctoral Dissertation]. São Paulo: Universidade de São Paulo; 2011. 


\section{Resumo}

O estudo teve como objetivos identificar o padrão de distribuição da hanseníase em um município brasileiro hiperendêmico e determinar a relação com o quadro clínico-epidemiológico ao longo de 11 anos. Os casos novos foram analisados com o sistema de informação geográfica, MapInfo, estatística scan espacial e indice Moran I. A base cartográfica digital foi usada para mapear os clusters de casos paucibacilares e multibacilares novos e casos em menores de 15 anos. Os indicadores socioeconômicos são mostrados através da técnica de mapeamento coroplético. Entre 2006 e 2010, foram observados uma redução no coeficiente de detecção, aumento no clusters espaciais de alto risco, mudanças marcantes na distribuição de clusters de alto e baixo risco e clusters de alto risco em menores de 15 anos, sugerindo doença recente, a presença de focos ativos e a sobreposição de clusters de alto risco para infecção multibacilar em menores de 15 anos. A hanseníase persiste enquanto problema de saúde pública em Rondonópolis, Mato Grosso; as áreas de alto risco exigem a intensificação de medidas de controle, além de estratégias de busca ativa para detectar casos novos.

Análise Espacial; Sistemas de Informação Geográfica; Fatores Epidemiológicos

\section{Resumen}

Este estudio tuvo como objetivo identificar la distribución de los patrones de lepra en una municipalidad hiperendémica en Brasil y determinar su relación con la situación clínico-epidemiológica durante 11 años. El sistema de información geográfica, MapInfo, estadísticas de escaneo espacial $y$ el indice de Moran se usaron para analizar nuevos casos. La base cartográfica digital se usó para mapear clústeres de nuevos casos multibacilares y paucibacilares, así como casos en menores por debajo de 15 años de edad. Los indicadores socioeconómicos se presentan usando la técnica de mapeo de coropletas. La reducción en la detección del coeficiente, se incrementa en los clústeres de alto riesgo espaciales, asimismo, se observaron de 2006 a 2010 cambios considerables en la distribución de los clústeres de alto riesgo y bajo riesgo, así como en clústeres de alto riesgo con menores con menos de 15 años de edad, mostrando los casos de enfermedad reciente la presencia de focos activos, así como solapando clústeres de alto riesgo de infección multibacilar en menores por debajo de los 15 años de edad. La lepra continúa siendo un problema de salud pública en Rondonópolis, Mato Grosso; las áreas de alto riesgo necesitan una intensificación de las medidas de control y una búsqueda activa de estrategias, con el fin de detectar nuevos casos.

Análisis Espacial; Sistemas de Información

Geográfica; Factores Epidemiológicos
Submitted on 18/Nov/2016

Versão final reapresentada em 12/Mar/2018 Aprovado em 23/Mar/2018 